\title{
PENERAPAN MODEL PEMROSESAN INFORMASI PADA PEMBELAJARAN MEMBACA SISWA DI SMP NEGERI 02 BENGKULU UTARA
}

\author{
Septiani Khotijah ${ }^{1}$, Agus Trianto ${ }^{2}$, dan Padi Utomo ${ }^{3}$ \\ ${ }^{1,2,3}$ Program Studi Pendidikan Bahasa dan Sastra Indonesia \\ Jurusan Pendidikan Bahasa dan Seni \\ FKIP Universitas Bengkulu \\ anijut27@gmail.com
}

\begin{abstract}
Abstrak
Penelitian ini secara umum bertujuan untuk mendeskripsikan penerpan model pemrosesan informasi pada pembelajaran membaca siswa di SMP Negeri 02 Bengkulu Utara. Metode yang digunakan adalah deskriptif kualitatif. Subjek penelitian ini adalah guru bahasa Indonesia dan siswa kelas VII A yang terlibat dalam pembelajaran dengan penerapan model pemrosesan informasi. Teknik pengumpulan data menggunakan observasi, wawancara, tes, dan dokumentasi. Hasil penelitian menunjukkan penerapan model pemrosesan informasi dalam pembelajaran siswa sudah dapat dilihat melalui delapan fase model pemrosesan informasi yang terdiri dari fase motivasi, fase pemahaman, fase pemerolehan, fase penahanan, fase ingatan kembali, fase generalisasi, fase perlakuan dan fase umpan balik. Dalam penerapan model ini fase yang lebih sering dilakukan pada fase pemerolehan, fase penahanan, dan fase ingatan kembali, Namun penerapan model ini juga tidak terlepas dari fase motivasi, fase pemahaman, fase generalisasi, fase perlakuan, dan fase umpan balik. Penerapan model pemrosesan informasi dilakukan dengan 26 langkah pembelajaran pada pertemuan pertama dan 19 langkah pembelajaran pada pertemuan kedua. Hasil kemampuan membaca yang diperoleh siswa dengan tugas yang berbeda-beda pada tiap pertemuan pembelajaran, memperoleh hasil yang termasuk ke dalam kategori baik. Dapat diketahui pada pertemuan pertama rata-rata kelas memperoleh skor 79,4 dengan ketuntasan klasikal siswa $81 \%$. Pertemuan kedua rata-rata kelas memperoleh skor 79,5 dengan ketuntasan klasikal siswa 85\% dan tugas diluar Rencana Pelaksanaan Pembelajaran (RPP), rata-rata kelas memperoleh skor 81 dengan ketuntasan klasikal $100 \%$. Berdasarkan hasil dan pembahasan, model pemrosesan informasi efektif digunakan pada pembelajaran membaca.
\end{abstract}

Kata Kunci: model pemrosesan informasi, pembelajaran membaca.

\begin{abstract}
This research generally aims to identify and describe the application of the information processing model of learning to read student at SMP Negeri 02 North Bengkulu. The method used is qualitative descriptive. This subjects were Indonesian teachers and students of class VII A involved in learning with the application of information processing. Data collection techniques are observation, interviews, test, and documentation. The results show that the application of information processing model in student learning can be seen through eight phases of information processing model consisting of motivation phase, understanding phase, acquisition phase, holding phase, recall phase, generalization phase, treatment phase and feedback phase.
\end{abstract}


In the application of this model the more frequent phases are in the acquisition phase, the holding phase, and the retention phase, but the application of this model is also inseparable from the motivation phase, understanding phase, generalization phase, treatment phase, and feedback phase. The application of the information processing model was carried out with 26 learning steps at the first meeting and 19 learning steps at the second meeting. The results of reading ability obtained by students with different tasks at each learning meeting, obtained results that fall into either category. Can be known at the first meeting the average class score 79.4 with students' classical completeness $81 \%$. The second meeting of the average class score 79.5 with students' classical completeness $85 \%$ and the task outside the Lesson Plans (RPP), the average class scored 81 with $100 \%$ classical completeness. Based on the results and discussion, the information processing model is effectively used in learning to read.

\section{Keywords: information processing model, learning to read.}

\section{PENDAHULUAN}

Bahasa memiliki dua ragam, yaitu ragam bahasa lisan dan ragam bahasa tulis. Kedua ragam tersebut sama pentingnya untuk berkomunikasi di dalam menjalani kedidupan sehari-hari. Ketika berkomunikasi diperlukan keterampilan berbahasa yang telah dimiliki. Ada orang yang telah memiliki keterampilan berbahasa yang baik, tetapi ada pula orang yang belum dapat mengoptimalkan keterampilan berbahasanya.

Keterampilan berbahasa pada saat ini semakin dibutuhkan mengingat perkembangan ilmu pengetahuan dan teknologi mengalami perkembangan yang begitu pesat. Perkembangan yang sangat pesat mengharuskan orang-orang untuk dapat bergerak dan berfikir dengan cepat untuk mengikuti perkembangan zaman dan mengelolanya agar tidak ketinggalan informasi dengan melibatkan keterampilan berbahasa. Seseorang harus dapat berfikir dengan cepat untuk memahami atau memaknai suatu hal, baik dalam bentuk lisan maupun tulisan. Kegiatan memahami atau memaknai suatu hal dalam bentuk tulisan merupakan salah satu keterampilan berbahasa yaitu membaca.
Membaca menjadi salah satu kegiatan yang penting. Melalui kegiatan membaca, seseorang akan memperoleh pemahaman dari tulisan-tulisan atau suatu bahan bacaan yang dapat dikembangkan menjadi suatu informasi. Pemahaman yang diperoleh dari tulisan atau bahan bacaan berupa pengetahuan dan wawasan yang dapat berguna bagi diri pembaca. Menurut Abidin (2012:147) membaca juga dapat dikatakan sebagai proses untuk mendapatkan informasi yang terkandung dalam teks bacaan untuk memperoleh pemahaman atas bacaan tersebut.

Banyaknya ilmu pengetahuan yang disajikan dalam bentuk tulisan menyebabkan keterampilan membaca tidak dapat diabaikan begitu saja. Oleh sebab itu, keterampilan membaca menjadi suatu hal yang penting untuk dipelajari.

Di lingkungan sekolah atau di dalam proses pembelajaran, peserta didik butuh diajarkan keterampilan membaca untuk dapat memahami tulisan-tulisan tersebut. Jika peserta didik dapat mengoptimalkan keterampilan membacanya, umumnya peserta didik tersebut menjadi siswa yang cerdas karena memiliki pengetahuan yang lebih luas. 
Melakukan pembelajaran membaca kepada siswa tidak semudah yang dibayangkan, karena membaca merupakan proses yang kompleks. Hal ini menyebabkan pelaksanaan pembelajaran membaca tidak selalu berjalan dengan lancar Ada beberapa masalah yang biasanya ditemukan dalam pembelajaran membaca.

SMP Negeri 02 Bengkulu Utara adalah sekolah yang cukup besar, memiliki fasilitas yang cukup dan memiliki siswa-siswi yang kemampuannya berbeda-beda. Ketika melaksanakan observasi pada siswa-siswa di kelas VIII dalam kegiatan magang di SMP Negeri 02 Bengkulu Utara, yang diamati adalah kegiatan guru dan siswa yang terlibat dalam kegiatan belajar tersebut. Pembelajaran yang dilakukan yaitu menggunakan teks fabel dengan media karton bergambar. Siswa yang mengikuti pembelajaran sebenarnya sudah aktif namun kebanyakan siswa aktif dalam berbicara halhal yang tidak penting di dalam kelas. Guru juga sebenarnya sudah baik melaksanakan pembelajaran karena sudah ada bantuan karton bergambar. Namun, nampaknya pembelajaran semacam itu kurang mampu mengarahkan konsentrasi siswa untuk memhami bahan bacaan dan mengutarkan kembali pemahamannya di depan kelas.

Secara umum, masalah yang terjadi pada pembelajaran membaca yaitu lemahnya proses pembelajaran. Pembelajaran membaca dirasa kurang terkonsep untuk melaksanakan proses pembelajaran dengan baik. Secara khusus masalah yang terjadi pada pembelajaran membaca yaitu peserta didik sulit memahami isi bacaan sehingga sedikit informasi yang diperoleh, pembelajaran membaca diajarkan biasa-biasa saja kurang memperhatikan penggunaan model pembelajaran, keterbatasan sarana dalam membaca, seperti ketersediaan buku-buku di perpustakaan kurang bervariasi dan suasana belajar yang kurang mengarahkan siswa untuk membaca.

Permasalahan yang diuraikan di atas berbanding terbalik dengan kurikulum 2013. Pada pembelajaran membaca menggunakan teks fabel, yang ingin dicapai adalah pada KD 3.11 Mengidentifikasi informasi tentang fabel/ legenda daerah setempat yang dibaca dan didengar dan pada KD 4.11 Menceritakan kembali isi cerita teks fabel/legenda daerah setempat yang dibaca/didengar. Dengan demikian, menurut Oka (1983:67) tugas pokok pengajaran membaca ialah membina siswa dalam bidang membaca. Seperti cara pandang kurikulum 2013 yang lebih menajamkan efek komunikasinya dan dampak fungsi sosialnya.

Selain itu, permasalahan yang terjadi dalam proses pembelajaran perlu ditinjau dari komponen-komponen utama yang ada dalam pembelajaran. Komponen-komponen utama itu meliputi guru, siswa, dan model pembelajaran. Ketiga komponen tersebut memiliki hubungan satu dengan yang lainnya. Jika dilihat dari permasalahan umum mengenai lemahnya proses pembelajaran, proses pembelajaran dapat ditingkatkan melalui model pembelajaran yang digunakan. Jika model pembelajaran yang digunakan sudah terkonsep dengan baik, guru dan siswa yang terlibat dalam pembelajaran tersebut juga akan baik. Model pembelajaran dibutuhkan untuk membantu memudahkan atau menjelaskan proses pembelajaran.

Salah satu model pembelajaran yang dapat digunakan untuk pembelajaran membaca siswa yaitu model pemrosesan informasi. Model pemrosesan informasi adalah model pemrosesan informasi menjelaskan bagaimana cara individu memberi respon yang datang dari lingkungannya dengan cara 
mengorganisasikan data, memformulasikan masalah, membangun konsep dan rencana pemecahan masalah, serta penggunaan simbol-simbol verbal dan nonverbal (Fathurrohman, 2015:34).

Berdasarkan pemaparan di atas mengenai beberapa masalah yang muncul mengenai pembelajaran membaca siswa, pada penelitian ini secara umum masalah lebih ditekankan padabagai manakah penerapan model pemrosesan informasi dalam pembelajaran membaca siswa kelas VII SMP Negeri 02 Bengkulu Utara? dan secara khusus (1) bagaimana penerapan model pemrosesan informasi yang dilakukan oleh guru dalam pembelajaran membaca siswa? dan (2) bagaimana hasil kemampuan membaca siswa yang diperoleh dari penerapan model pemrosesan informasi? Adapun tujuan penelitian penerpan model pemrosesan informasi pada pembelajaran membaca siswa di SMP Negeri 02 Bengkulu Utara, yaitu (1) untuk mendeskripsikan penerapan model pemrosesan informasi yang dilakukan oleh guru dalam pembelajaran membaca siswa dan (2) untuk mendeskripsikan hasil kemampuan membaca siswa yang diperoleh dari penerapan model pemrosesan informasi.

\section{METODE}

Metode yang digunakan dalam penelitian ini adalah metode desktiptif kualitatif. Metode deskriptif kualitatif adalah metode penelitian yang bertujuan untuk menggambarkan secara utuh dan mendalam tentang realitas sosial dan berbagai fenomena yang terjadi di masyarakat yang menjadi subjek penelitian sehingga tergambarkan ciri, karakter, sifat, dan model dari fenomena tersebut (Sanjaya,2014:47). Berdasarkan pendapat tersebut, metode deskriptif kualitatif dalam penelitian ini digunakan untuk mendeskripsikan kegiatan guru dalam menerapkan model pemrosesan informasi pada pembelajaran membaca, mendeskripsikan aktivitas yang dilakukan oleh siswa ketika menerima pembelajaran, dan mendeskripsikan hasil belajar siswa setelah menerima pembelajaran model pemrosesan informasi pada pembelajaran membaca.

Penelitian ini dilaksanakan pada kelas VII A di SMP Negeri 02 Bengkulu Utara pada bulan Februari tahun ajaran 2016/2017 yang beralamat di Jl. Ratu Samban No. 12 Arga Makmur Bengkulu Utara. Ada beberapa alasan dalam memilih lokasi di SMP Negeri 02 Bengkulu Utara yang pertama karena SMP Negeri 02 Bengkulu Utara termasuk sekolah yang cukup diminati oleh siswa-siswi yang ada di Arga Makmur dan alasan yang kedua karena SMP Negeri 02 Bengkulu Utara termasuk sekolah yang besar dan memiliki fasilitas yang cukup. Alasan memilih kelas VII A sebagai kelas penelitian karena semua kelas VII di SMP Negeri 02 Bengkulu Utara umumnya sama saja, tidak ada kelas yang diunggulkan oleh sebab itu kelas pertama atau kelas $A$ yang dipilih untuk melakukan penelitian. Selain itu, siswa-siswi yang berada di kelas VII A cukup heterogen.

Data adalah hasil pencatatan penelitian yang menjadi tujuan utama dalam penelitian. Data dalam penelitian ini adalah berupa ujaran, kegiatan, tingkah laku, dan hasil pembelajaran. Data utama dalam penelitian kualitatif adalah kata-kata dan tindakan selebihnya adalah data tambahan seperti penilaian pengamat dan dokumen. Sumber data dalam penelitian ini adalah kegiatan guru dalam menerapkan model pemrosesan informasi, aktivitas siswa dalam mengikuti pembelajaran dengan model pemrosesan informasi, dan hasil belajar siswa serta hasil penilaian terhadap guru yang menerapkan model pemrosesan informasi. 
Instrumen penelitian yang digunakan dalam penelitian ini adalah peneliti itu sendiri. Seorang peneliti perlu melakukan validasi. Validasi terhadap peneliti sebagai instrumen dilakukan oleh peneliti sendiri, melalui evaluasi diri seberapa jauh pemahaman terhadap metode kualitatif, penguasaan teori dan wawasan terhadap bidang yang diteliti, serta kesiapan dan bekal memasuki lapangan (Sugiyono,2014:222).

Peneliti sebagai instrumen utama berfungsi menetapkan fokus penelitian, memilih informan sebagai sumber data, melakukan pengumpulan data, menilai kualitas data, analisis data, menafsirkan data dan membuat kesimpulan atas temuannya. Setelah menetapkan fokus penelitian menjadi jelas, maka instrumen penelitian akan dikembangkan yaitu menggunakan wawancara dan observasi yang diharapkan dapat melengkapi data (Sugiyono, 2014:222223).

Pengumpulan data dapat dilakukan dalam berbagai setting, berbagai sumber, dan berbagai cara. Ada bermacam-macam teknik pengumpulan data yang dapat digunakan dalam penelitian, yaitu observasi, wawancara, tes, dan dokumentasi. Observasi pada penelitian ini dilakukan dengan melakukan pengamatan menggunakan alat indera dengan perhatian yang penuh. Observasi dilakukan ketika proses belajarmengajar bahasa Indonesia sedang berlangsung. Pengamatan dilakukan sebanyak dua kali, dan setiap pengamatan dilakukan dengan pencatatan lapangan. Observasi yang dilakukan adalah observasi nonpartisipan, artinya peneliti tidak ikut dalam kegiatan belajar mengajar, akan tetapi hanya mengamati kegiatan guru dan siswa dalam menerapkan model pemrosesan informasi pada pembelajaran membaca siswa kelas VII SMP Negeri 02 Bengkulu Utara.
Wawancara yang digunakan dalam penelitian ini adalah wawancara terstruktur. Wawancara terstruktur dilakukan dengan menyiapkan instrumen penelitian berupa pertanyaan-pertanyaan tertulis yang alternatif jawabannya pun telah disiapkan (Sugiyono,2014:233). Wawancara ini ditujukan kepada guru dan siswa yang terlibat dalam pembelajaran membaca di kelas VII dengan pencatatan langsung dan dokumentasi. Wawancara ini digunakan sebagai data pelengkap yang bertujuan untuk menanyakan hal-hal yang belum terungkap melalui kegiatan pengamtan.

Tes kemampuan membaca siswa pada penelitian ini menggunakan tes subjektif dan tes menceritakan kembali. Dokumen berupa catatan peristiwa yang sudah berlalu. Pengumpulan data yang terakhir melalui dokumen. Dokumen bisa berbentuk tulisan, gambar, atau karya-karya monumental dari seseorang. Dokumen merupakan pelengkap dari penggunaan observasi dan wawancara dalam suatu penelitian. Hasil penelitian dari observasi dan wawancara akan semkin kredibel/dapat dipercaya kalau didukung oleh sejarah pribadi kehidupan di masa kecil, sekolah, di tempat kerja, di masyarakat, dan autobiografi. Namun tidak semua dokumen memiliki kreadibilitas yang tinggi (Sugiyono, 2014: 240).

Pada penelitian ini teknik analisis data yang digunakan yaitu menggunakan teknik analisis data model Miles dan Huberman. Menurut Miles dan Huberman dalam Sugiyono (2014: 246) mengemukakan bahwa aktivitas dalam analisis data kualitatif dilakukan secara interaktif dan berlangsung secara terus-menerus sampai tuntas, sehingga datanya sudah jenuh. Aktivitas dalam analisis data, yaitu data reduction, data display, dan conclusion drawing/verification. 
Triangulasi yang digunakan dalam penelitian ini yaitu triangulasi sumber. Triangulasi Sumber merupakan triangulasi yang digunakan untuk menguji kredibilitas data yang dilakukan dengan cara mengecek data yang telah diperoleh melalui beberapa sumber. Sebagai contoh, untuk menguji kredibilitas data tentang perilaku murid, maka pengumpulan dan pengujian data yang telah diperoleh dapat dilakukan ke guru, teman murid yang bersangkutan dan orang tuanya. Data dari ketiga sumber tersebut tidak bisa dirata-ratakan seperti penelitian kuantitatif, tetapi dideskripsikan, dikategorikan, mana pandangan yang sama, yang berbeda, dan mana spesifik dari tiga sumber data tersebut.

\section{HASIL DAN PEMBAHASAN}

Berdasarkan hasil penelitian dari hasil observasi dan wawancara diperoleh data mengenai penerapan model pemrosesan informasi yang dilakukan oleh guru pada pembelajaran membaca siswa di SMP Negeri 02 Bengkulu Utara dan hasil kemampuan membaca yang diperoleh siswa dari penerapan model pemrosesan informasi. Langkah-langkah pembelajaran yang dilaksanakan di kelas dikelompokkan menjadi delapan fase sesuai dengan delapan fase model pemrosesan informasi. Menurut Robert M. Gagne dalam Rusman (2014:139), Surya (2014:147-148), Fathurrohman (2015:35) mengemukakan ada delapan fase proses pembelajaran model pemrosesan informasi, antara lain (1) motivasi, (2) pemahaman, (3) pemerolehan, penahanan, (5) ingatan kembali, (6) generalisasi, (7) perlakuan, (8) umpan balik.

Pada pelaksanaan pembelajaran di kelas, guru pada awal pembelajaran sudah memberikan motivasi kepada siswa. Motivasi diberikan setelah guru membuka pembelajaran, mengkondisikan kelas, menanyakan kehadiran siswa, dan menghubungkan materi pembelajaran dengan materi yang telah dipelajari. Motivasi yang diberikan guru tidak selalu yang berkaitan dengan materi pelajaran. Motivasi yang diberikan guru cukup sederhana tetapi bisa membuat siswa semangat atau antusias mengikuti pembelajran pada hari itu. Motivasi yang dilakukan oleh guru sudah sesuai, hal ini dikuatkan dengan pendapat Robert M. Gagne dalam Rusman (2014:139), Surya (2014:147-148), Fathurrohman (2015:35), bahwa motivasi adalah fase awal memulai pembelajaran dengan adanya dorongan untuk melakukan suatu tindakan dalam mencapai tujuan tertentu (motivasi instrinsik dan ekstrinsik).

Menurut Robert M. Gagne dalam Rusman (2014:139), Surya (2014:147-148), Fathurrohman (2015:35) pemahaman yaitu individu menerima dan memahami informasi yang diperoleh dari pembelajaran. Pemahaman didapat melalui perhatian. Berdasarkan pendapat tersebut sudah sesuai dengan yang dilakukan oleh guru. Pada saat pelaksanaan pembelajaran, guru memberikan pemahaman kepada siswa tidak secara langsung dari guru tetapi diperoleh dari pengetahuan yang ada pada siswa itu sendiri. Pada hari pertama, pemahaman yang diberikan kepada siswa dilakukan dengan cara tanya jawab. Tanya jawab ini dilakukan untuk menggali pengetahuan yang sudah dimiliki siswa atau siswa dapat berfikir terlebih dahulu mengenai materi yang akan dipelajarinya tidak sekedar menerima saja penyampaian dari guru. Hal ini juga berkitan dengan salah satu strategi yang ada dalam model pemrosesan informasi yaitu latihan inquiry. Menurut Rusman (2014:140) latihan Inquiry, yaitu untuk mencari dan menemukan informasi yang memang diperlukan. Selain itu, penyampaian materi dengan cara yang telah dipilih guru tersebut 
juga sudah sesuai dengan pembelajaran sebenarnya. Dengan singkat dapat dinyatakan bahwa peranan guru dalam mengelola proses pembelajaran, dari guru sebagai sumber belajar menjadi guru sebagai fasilitator dalam pembelajaran (Fathurrohman, 2015:15). Begitu juga pembelajaran yang terjadi di pertemuan kedua. Guru menanyakan materi yang dipelajari pada pertemuan pertama agar siswa mengingat kembali dan arah pembelajaran pertemuan kedua semakin terarah. Guru juga meyakinkan siswa agar dapat percaya diri dengan memperjelas isi dari teks fabel.

Kegiatan pembelajaran pada saat itu yang termasuk dalam fase pemerolehan, siswa menerima penyampaian Kompetensi Dasar (KD) penyampaian tujuan pembelajaran dan menerima penyampaian materi atau penjelasan materi berdasarkan tanya jawab yang telah dilakukan pada fase pemahaman. Penyampaian Kompetensi Dasar dan tujuan pembelajaran pada fase ini diharapkan agar siswa lebih mengetahui atau tertanam ke dalam pikiran siswa mengenai pelajaran yang akan dilakukannya bersama guru dan penyampaian materi dilakukan agar siswa tidak hilang arah atau kebingungan tentang materi fabel. Selain itu juga sebagai penjelasan materi agar siswa mengetahui yang benar dan yang salah dari jawaban yang telah diberikan siswa atas pertanyaan guru pada sesi tanya jawab pada fase pemahaman, sehingga siswa benarbenar memperoleh cakupan materi pembelajaran. Begitu juga pada pertemuan kedua, fase pemerolehan dilakukan dengan menyampaian KD (Kompetensi Dasar), penyampaian tujuan, dan mempersiapkan siswa untuk menceritakan kembali.

Selain itu, pemebelajaran yang dilakukan pada fase pemerolehan yaitu kegiatan mengamati dan menanya. Pada kegiatan mengamati, dua orang siswa dipilih untuk membaca kedua teks. Siswa yang pertama dipilih perempuan untuk membaca teks "Belalang Sembah" dan siswa yang kedua dipilih laki-laki untuk membaca teks "Sesama Saudara Harus Berbagi" dan kemudian semua siswa kelas VII A diberikan kesempatan untuk membaca kedua teks hingga selesai. Sedangkan pada pertemuan kedua, guru hanya memilih dua orang siswa untuk membaca dengan nyaring kedua teks fabel. Membaca yang dilakukan siswa ada dua jenis yaitu membaca nyaring dan membaca dalam hati. Membaca yang dilakukan pada hari itu membaca teks fabel secara keseluruhan.

Menurut Robert M. Gagne dalam Rusman (2014:139), Surya (2014:147-148), Fathurrohman (2015:35) penahanan adalah menahan informasi/hasil belajar agar dapat digunakan untuk jangka panjang. Hal ini merupakan proses mengingat jangka panjang. Berdasarkan pengertian penahanan tersebut, langkah-langkah pembelajaran yang dilakukan guru pada fase ini sudah cukup tepat. Pada pertemuan pertama, guru awalnya membentuk siswa secara berkelompok, kemudian guru memberikan penjelasan mengenai tugas yang akan di kerjakan oleh siswa. Siswa diberikan tiga soal. Ketiga soal yang diberikan kepada siswa berkiatan dengan langkah-langkah pembelajaran menggunakkan penghapalan/memorisasi pada model pemrosesan informasi. Menurut Joyce, Weil, dan Calhoun (2011:240-241) kegiatan tersebut berada di tahap pertama yaitu mempersiapkan materi, dengan langkahlangkahnya, (1) menggunakan teknik-teknik yang mencakup menggarisbawahi (underlining), (2) membuat daftar (listing), dan (3) merefleksikan (reflecting).

Pada fase ingatan kembali siswa diminta untuk menyampaikan apa yang telah 
dilakukannya atau menyampaikan tugas yang dikerjakannya. Guru memberikan bimbingan kepada siswa ketika menyampaikan tugas. Pertemuan pertama, ingatan kembali dilakukan dengan cara guru memilih perwakilan kelompok untuk menyampaikan hasil belajar dari tugas mencari unsur intrinsik yang terdapat dalam teks "Belalang Sembah dan "Sesama Saudara Harus Berbagi" dan pertemuan kedua, ingatan kembali dilakukan dengan cara siswa dipilih secara acak untuk tampil di depan kelas menceritakan kembali salah satu teks antara dua teks yang telah diberikan. Tindakan yang dilakukan oleh guru pada fase ingatan kembali ini cukup sesuai. Hal ini dapat dilihat dengan definisi ingatan kembali. Menurut Robert M. Gagne dalam Rusman (2014:139), Surya (2014:147-148), Fathurrohman (2015:35) ingatan kembali adalah mengeluarkan kembali informasi yang telah disimpan, bila ada rangsangan.

Kegiatan guru di kelas tidak sepenuhnya dapat dikatakan sebagai tindakan fase generalisasi karena di dalam kelas guru hanya memberikan penghatian dan nasehat kepada siswa bahwa pembelajaran yang dilakukan di kelas ini sebetulnya akan sangat bermanfaat dikehidupan nyata. Namun, guru tidak bisa selalu memantau apakah siswa mengeneralisasikan ilmu yang telah dia peroleh dikehidupannya sehari-hari.

Pada fase perlakuan ini, guru memberikan bimbingan kepada siswa untuk menyimpulkan materi pembelajaran di kelas. Hal ini dilakukan agar guru mengetahui apakah materi yang dipelajari pada hari itu dapat dipahami oleh siswa. Selain itu, guru juga bertanya kepada siswa mengenai hambatan yang mereka temukan ketika belajar. Perlakuan yang diberikan oleh guru di bagian akhir-akhir pembelajaran ini sudah cukup baik dan sesuai. Hal tersebut diperkuat dengan pengertian perlakuan Menurut Robert M. Gagne dalam Rusman (2014:139), Surya (2014:147-148), Fathurrohman (2015:35) bahwa perlakuan adalah perwujudan perubahan perilaku individu sebagai hasil pembelajaran.

Umpan balik yang diberikan guru pada pertemuan pertama guru memberikan nasehat kepada siswa untuk terus belajar dan memberikan penjelasan mengenai tindak lanjut pembelajaran yang akan dilakukan pada pertemuan kedua. Pada pertemuan kedua, guru memberikan nasihat atau motivasi kepada siswa untuk terus belajar, tidak malas-malasan dan agar tidak putus sekolah. Umpan balik yang diberikan guru tersebut sudah cukup sesuai tetapi ada baiknya pula jika guru memberikan pujipujian kepada siswa atas apa yang telah di pelajarinya pada akhir pembelajaran ini. Seperti umpan balik yang dikemukakan Robert M. Gagne dalam Rusman (2014:139), Surya (2014:147-148), Fathurrohman (2015:35) bahwa umpan balik adalah individu memperoleh feedback dari perilaku yang telah dilakukannya.

Berdasarkan fase-fase model pemrosesan informasi di atas, guru telah melaksanakan pembelajaran dengan menerapkan model pemrosesan informasi dalam pembelajaran membaca sudah sesuai dengan Rencana Pelaksanaan Pembelajaran (RPP). Meskipun ada beberapa hal yang tidak sama persis dengan Rencana Pelaksanaan Pembelajaran.

Setelah diterapkan model pemrosesan informasi pada pembelajaran membaca di kelas, siswa sudah dapat mengerjakan tugas dengan baik dan menceritakan kembali dengan baik. Ketika model pemrosesan informasi diterapkan di kelas VII A, terlihat jelas siswa begitu bersemangat mengikuti pembelajaran. Ketika diberikan pertanyaan siswa 
menanggapi dan memberikan jawaban dengan baik. Begitu juga ketika siswa diberikan kesempatan untuk membaca, siswa membaca dengan begitu antusias. Dua orang siswa yang dipilih untuk membaca nyaring juga begitu antusias, terhihat dari kejelasan siswa ketika membaca dan juga ketika semua siswa diberikan kesempatan membaca, kelas menjadi sedikit sunyi. Hal ini menandakan kalau siswa serius membaca kedua teks yang diberikan.

Dalam pembelajaran terjadi proses penerimaan informasi yang kemudian diolah sehingga menghasilkan output dalam bentuk hasil belajar. Dalam model pemrosesan informasi terjadi interaksi antara kondisi internal (keadaan individu, proses kognitif) dan kondisi-kondisi eksternal (rangsangan dari lingkungan) dan interaksi antar keduanya akan menghasilkan hasil belajar.

Dengan melaksanakan kegiatan pembelajaran dengan menerapkan model pemrosesan informasi, pada pertemuan pertama hasil yang diperoleh siswa tergolong baik dengan skor rata-rata kelas 79,4. Skor yang diperoleh tersebut berdasarkan tugas siswa untuk mencari unsur intrinsik fabel dengan cara menggarisbawahi (underlining) teks kemudian mendaftar (listing) unsur-unsur intrinsik yang telah ditemukan dari teks fabel "Belalang Sembah" dan "Sesama Saudara Harus Berbagi." Hasil yang diperoleh tersebut sudah sesuai dengan ketentuan penilaian mengenai unsur-unsur intrinsik fabel yaitu tema, latar, tokoh, watak tokoh, konflik, amanat, cara penceritaan, tujuan komunikasi, alur, dan pesan. Sesuai dengan pendapat Nurgiyantoro (2014: 253) pedoman kriteria dengan sekala empat 7585 masuk ke dalam kategori baik. Jadi, hasil belajar siswa dengan membaca teks "Belalang Sembah" dan "Sesama Saudara Harus Berbagi" untuk mencari unsur intrinsik dengan penerapan model pemrosesan informasi berada dalam kategori baik yaitu sebesar 79,4. Selain skor rata-rata siswa yang berada dalam kategori baik, presentase ketuntasan klasikal siswa juga telah menunjukkan hasil yang baik sebesar $81 \%$.

Pada pertemuan kedua, hasil belajar yang diperoleh siswa juga baik. Skor ratarata kelas yang diperoleh 79,5 . Skor tersebut diperoleh dari tugas siswa untuk menceritakan kembali teks fabel "Belalang Sembah" atau "Sesama Saudara harus Berbagi" dengan cara memilih di antara kedua teks tersebut. Skor rata-rata yang telah diperoleh tersebut tidak menunjukkan peningkatan atau dapat dikatakan skor ratarata kelas pada pertemuan pertama dan kedua rata-ratanya sama. Namun, hal ini bukanlah hal yang buruk. Skor rata-rata kelas tersebut, diperoleh dari ketentuan atau aspek-aspek penilaian yang telah ditetapkan sebelumnya yang terdiri dari 6 aspek penilaian yaitu, kesesuaian isi, kemenarikan penyajian cerita, kelancaran, pilihan kata (diksi), volume suara, dan penampilan. Skor rata-rata kelas pertemuan kedua termasuk dalam kategori baik karena rata-ratanya juga sesuai dengan pedoman kriteria dengan sekala empat menurut Nurgiyantoro (2014: 253) bahwa nilai $75-85$ masuk ke dalam kategori baik. Jadi, hasil belajar siswa membaca teks fabel dengan tugas menceritakan kembali teks "Belalang Sembah" atau "Sesama Saudara Harus Berbagi" memperoleh hasil yang baik. Selain itu, ketuntasan klasikal yang diperoleh pada pertemuan kedua menunjukkan hasil yang baik sebesar $85 \%$.

Selain tugas yang diberikan pada pertemuan pertama dan pertemuan kedua, semua siswa diberikan teks yang berjudul "Ikan Gabus dan Tupai" dengan 5 butir soal yang harus dikerjakan siswa secara individu. Berdasarkan tugas tersebut, hasil yang 
diperoleh siswa baik dengan skor rata-rata kelas sebesar 81. Skor tersebut diperoleh sesuai dengan kriteria penilaian mengenai soal-soal yang diberikan kepada siswa. Soal yang diberikan kepada siswa mencakup definisi teks fabel beserta ciri khas teks fabel dan penjelasannya, unsur intrinsik teks fabel, alasan Tupai menyelamatkan Ikan gabus, proses Tupai menyelamatkan Ikan Gabus, dan pesan yang ingin disampaikan oleh penulis. Berdasarkan skor rata-rata kelas tersebut, menurut Nurgiyantoro (2014:253) mengenai pedoman kriteria dengan skala empat menunjukkan rentang nilai 75-85 berada dalam kategori baik. Selain skor ratarata kelas, ketuntasan klasikal siswa pada tugas ini juga menunjukkan hasil yang sempurna sebesar $100 \%$.

Berdasarkan ketiga tugas siswa yang telah dikerjakan, hasil belajar dengan penerapan model pemrosesan informasi pada pembelajaran membaca siswa dapat dikatakan berhasil karena hasil belajar dikatakan tuntas jika $75 \%$ dari siswa yang ada di kelas memperoleh nilai minimal 75 atau mendapatkan nilai sesuai Kriteria Ketuntasan Minimal (KKM) sebesar 75. Berdasarkan hal tersebut, jika dalam satu kelas ketuntasan yang diperoleh dari $75 \%$ siswa sebesar 75, maka pembelajaran yang dilakukan dapat dikatakan berhasil. Dalam penelitian ini, presentase ketuntasan klasikal siswa pada pertemuan pertama sebesar $81 \%$, pertemuan kedua $85 \%$, dan tugas di luar RPP menunjukkan hasil yang sempurna yaitu $100 \%$. Hal tersebut menujukkan bahwa pada pertemuan pertama ada empat siswa yang belum tuntas. Pertemuan kedua ada tiga siswa yang belum tuntas dan tugas di luar RPP menunjukkan tidak ada satu pun siswa yang tidak berhasil menembus batas Kriteria Ketuntasan Minimal (KKM).

\section{PENUTUP}

\section{Kesimpulan}

Berdasarkan masalah yang telah diajukan, hasil yang diperoleh dari penerpan model pemrosesan informasi pada pembelajaran membaca siswa di SMP Negeri 02 Bengkulu Utara, dapat disimpulkan, yaitu (1) Penerapan model pemrosesan informasi pada pembelajaran membaca siswa di SMP Negeri 02 Bengkulu Utara telah dilaksanakan sesuai dengan Rencana Pelaksanaan Pembelajaran (RPP) yang telah dibuat. Penerapan dilakukan dengan 26 langkah pembelajaran pada pertemuan pertama dan 19 langkah pembelajaran pada pertemuan kedua. Langkah-langkah pembelajaran tersebut telah dilaksanakan pada kegiatan awal, inti, dan penutup. Langkah-langkah pembelajaran yang dilakukan secara fleksibel dengan menerapkan model pemrosesan informasi yang terdiri atas delapan fase proses pembelajaran, yaitu motivasi, pemahaman, pemerolehan, penahanan, ingatan kembali, generalisasi, perlakuan, dan umpan balik. Oleh karena itu, hasil peneran model pemrosesan informasi pada pembelajaran membaca siswa di SMP Negeri 02 Bengkulu Utara sudah dilaksanakan sesuai dengan fase-fase pembelajaran dan (2) Hasil belajar siswa kelas VII A SMP Negeri 02 Bengkulu Utara dengan menerapkan model pemrosesan informasi, memperoleh skor rata-rata kelas yang berada pada kategori baik. Pertemuan pertama skor ratarata kelas sebesar 79,4 dengan ketuntasan klasikal siswa $81 \%$. Pertemuan kedua skor rata-rata sebesar 79,5 dengan ketuntasan klasikal siswa $85 \%$ dan tugas diluar Rencana Pelaksanaan Pembelajaran (RPP) skor ratarata kelas sebesar 81 dengan ketuntasan klasikal 100\%. Berdasarkan skor yang diperoleh tersebut, dapat dikatakan bahwa penerapan model pemrosesan informasi 
dalam pembelajaran membaca siswa efektif untuk digunakan.

\section{Saran}

Berdasarkan hasil yang diperoleh tersebut, disarankan agar guru-guru di sekolah dapat memaksimalkan cara mengajarnya ataupun lebih menguasai model pemrosesan informasi pada pembelajaran keterampilan khususnya keterampilan membaca, agar selanjutnya kegiatan pembelajaran menjadi lebih baik. Disarankan pula kepada seluruh siswa yang terlibat di dalam proses pembelajaran, untuk terus aktif, kreatif dalam belajar dan tidak lupa juga untuk selalu memperhatikan dengan baik kriteria penilaian yang telah ditetapkan. Hal ini dilakukan agar seluruh siswa memperoleh hasil yang baik. Selain itu, untuk lebih memantapkan hasil dari model pemrosesan informasi, disarankan pula kepada penulis-penulis yang lain untuk dapat mencoba menerapkan model pemrosesan informasi di sekolah yang lain dan pada jenjang yang lain juga agar memperoleh wawasan yang lebih luas dan dapat dipercaya.

\section{DAFTAR PUSTAKA}

Abidin, Yunus. 2012. Pembelajaran Bahasa Berbasis Pendidikan Karakter. Bandung: PT Refika Aditama.
Fathurrohman, Muhammad. 2015. Modelmodel Pembelajaran Inovatif. Yogyakarta: Ar-Ruzz Media.

Joyce, Bruce, dkk. 2011. Model of Teaching. Model-Model Pengajaran. Yogyakarta: Pustaka pelajar.

Nurgiyantoro, Burhan. 2014. Penilaian Pembelajaran Bahasa Berbasis Kompetensi. Yogyakarta: BpfeYogyakarta.

Oka, I Gusti Ngurah. 1983. Pengantar Membaca \& Pengajarannya. Surabaya: Usaha Nasional.

Rusman. 2014. Model-Model Pembelajaran. Jakarta: PT RajaGrafindo Persada.

Sanjaya, Wina. 2014. Penelitian Pendidikan Jenis, Metode dan Prosedur. Jakarta: Kencana Prenada Media Group.

Sugiyono. 2014. Metode Penelitian Kuantitatif, Kualitatif dan R\&D. Bandung: Alfabeta.

Surya, Mohamad. 2014. Psikologi Guru Konsep dan Aplikasi dari Guru, untuk Guru. Bandung: Alfabeta. 